\title{
Latin American Jesuit Social Centers and Environmental Justice: Advocacy and Support to Local Communities and Knowledge-Building from below
}

\author{
Sergio Coronado Delgado \\ Cinep / Programa por la Paz, Bogotá, Colombia \\ scoronado@Cinep.org.co
}

\begin{abstract}
This article explores a possible answer to the broad question of how the Jesuits and their institutions contribute to environmental issues in Latin America. The paper focuses on the work of Latin American Jesuit social centers, specifically regarding mining issues. The main argument is that acute environmental conflicts caused by the mining boom in the region are being attended to by advocacy strategies inspired by the environmental justice movement. The article is divided into three sections: first, it describes the broad characteristics of the current mining boom in Latin America; second, it offers examples of the advocacy strategies developed by two Jesuit social centers in Colombia and Honduras; third, it analyzes the place of such work within the diverse currents of the environmentalism movement. It concludes by pursuing a connection between the advocacy work in question and relevant theological reflections widespread within the Jesuits, the Catholic Church, and the global society.
\end{abstract}

* Sergio Coronado Delgado (b.1981) is a researcher at the Center for Research and Popular Education (CINEP) and previously worked as a professor in the School of Environmental and Rural Studies at Pontificia Universidad Javeriana in Bogotá. He is a lawyer with Master's degrees in constitutional law and rural development. His work and research are related to human rights, land policy, territorial conflicts, and the indigenous rights to land, as well as Afro-descendant and peasant communities; www.cinep.org.co.

(C) CORONADO DELGADO, 2016 | DOI 10.1163/22141332-00304007

This is an open access article distributed under the terms of the Creative Commons Attribution-

Noncommercial 4.0 Unported (CC-BY-NC 4.0) License. http://creativecommons.org/licenses/by-nc/4,0//11:00:56AM 


\section{Keywords}

Latin America - advocacy - support - knowledge-building - environmental justice - mining

\section{Introduction}

During the last two decades, Jesuit social centers in Latin America have increased their concerns for-and accordingly their labors on behalf of environmental issues. At least three causes can be identified for this shift: rising environmental consciousness as a consequence of the emergence of sharp environmental conflicts, such as climate change; the destruction and degradation of crucial ecosystems like the Amazon forest, and others less widely known; the presence of environmental issues in Jesuit ministry, fostered by contact with local communities living with and suffering from the consequences of environmental destruction. Consequently, there is an urgent need to provide thoughtful and feasible alternatives for the current political, social, and economic challenges that are facing Latin American countries, demanding consideration of the environment and the ideal of sustainability.

Presently, Jesuit social centers and institutions make numerous efforts that are aimed at addressing environmental challenges. Some organizations have developed long-term projects to support rural communities in generating alternative models of development, which would be based on the sustainable use of natural resources. Other Jesuit institutions are focused on advocacy strategies through a human rights scope by presenting cases of violation of land and environmental rights to international human rights organizations, particularly the Inter-American Commission of Human Rights (IACHR). Meanwhile, other institutions are supporting research projects that examine socio-environmental issues, such as the direct impact of development-many of which relate to the aftermath of mining and other extractive activities - on the welfare of local communities. Particularly, this article discusses the work done by Centro de Investigación y Educación Popular (CINEP) in Colombia and Equipo de Reflexión, Investigación, y Comunicación (ERIC) in Honduras.

The objective of this article is to answer the question of how the social branch of the Conferencia de Provinciales Jesuitas de América (CPAL, Conference of the Jesuit provincials of America) is engaging with the environmental challenges faced by its constituent provinces. Accordingly, its focus in exploring and analyzing the role of Jesuits regarding a specific issue, namely mining, can provide a case study. Therefore, by way of rough approximation, we 
might assume that such work is a part of a broader strategy implemented by social centers in order to promote the fulfillment of human rights, a platform in which environmental justice is an essential dimension. It is relevant, nevertheless, to state that the articulation of these principles among the institutions involved is still a work-in-progress. This article thus attempts to provide a general overview of the current social and environmental conflicts within Latin America, particularly Colombia, in confronting consequences and predicaments that are posed by the mining boom of the last few decades. It concurrently examines the strategies deployed by regional Jesuit social centers and institutions as an ethical response to those varying circumstances. Finally, it concludes by correlating such positions to a heuristic model of environmental justice that is adopted from the scholarship of theorists such as Joan MartínezAllier, ${ }^{1}$ Carlos Walter Porto-Gonçalves, ${ }^{2}$ and Enrique Leff. ${ }^{3}$

\section{Mining Boom in Latin America: Characteristics and Outcomes}

Generally speaking, in Latin America the first decade and a half of the twentyfirst century might be characterized by the new economic boom of the extractive industries. The region as a whole is experiencing a steady increase in the extraction of minerals and other raw materials. The total Latin American output of these resources rose from 2,400 million tons in 1970 to nearly 8,300 million tons in 2009. ${ }^{4}$ In this period, the countries of the region continued to increase exports, mainly of hydrocarbons, minerals, and metals. In Colombia, one of the clearest cases in the region, raw materials rose from $66 \%$ of total exports in 2000 to more than $82 \%$ in 2011. Parallel trends, however, can be observed in Bolivia, with an increase from $72 \%$ to $95 \%$, and in Brazil, with an increase from $42 \%$ to $66 \%$, in the same period. ${ }^{5}$ Nevertheless, it is not yet possible to convert such increases in exports into substantive macroeconomic benefits. In the vast majority of Latin American countries, the export of raw

1 Joan Martínez Alier, The Environmentalism of the Poor: A Study of Ecological Conflicts and Valuation (Northampton, MA: Edward Elgar, 2002).

2 Carlos Walter Porto-Gonçalves, A globalizaçâo da natureza e a natureza da globalização (Rio de Janeiro: Civilização Brasileira, 2006).

3 Enrique Leff, La apuesta por la vida: Imaginación sociológica e imaginarios sociales en los territorios ambientales del sur (Mexico City: Siglo Veintiuno Editores, 2014).

4 OCMAL, "Environmental Justice Atlas: Mining Conflicts in Latin America," Ejolt, last modified March 1, 2014, http://ejatlas.org/featured/mining-latam (accessed June 13, 2016).

5 Hans-Jürgen Burchardt and Kristina Dietz, "(Neo-)extractivism: A New Challenge for Development Theory from Latin America," Third World Quarterly 35, no. 3 (2014): 468-86. 
materials does not cover the expenses of the import of other goods and services. The situation is even more bleak when we take into account the details of the commercial relationships between Latin American countries with the buyers of their commodities. For instance, in terms of volume, Colombia exports five times its imports - mainly composed of coal—and yet the country is unable to pay its imports with their exports, generating a problem with the country's balance of payments and new cycles of indebtedness. ${ }^{6}$

Regarding Central America, countries in fact possess significant reserves of precious and industrial minerals. However, the current extraction boom in that region is, according to Ismael Moreno, "being carried out more aggressively than has normally been done so far, and with serious social, political, and environmental consequences." ${ }^{7}$ According to recent reports, about fourteen percent of the territory of Central American countries is already granted for mining extraction, ${ }^{8}$ and countries like Guatemala, Honduras, and Nicaragua are currently experiencing an unusual increase in projects from international companies - mostly Canadian - to open mines. Guatemala, for instance, has thirty-three mines already working and there are another sixty-seven at an exploratory stage. Finally, there is a large amount of petitions from companies to have mining concessions: in Panama, there are 146 such requests; in Nicaragua, 122; in Honduras, 300; and in Guatemala, $355 .^{9}$

For the governments of Latin America as a whole, an increase in the export of raw materials also seems to equate to an increased dependence on the incomes and revenues that are directly associated with the mining sector, especially with respect to oil and natural gas. ${ }^{10}$ Nevertheless, this does

6 Joan Martínez Alier, “Argumentos económicos contra el extractivismo," Lajornada (June 21, 2014), http://www.jornada.unam.mx/2014/o6/21/opinion/o14aipol(accessedJune13, 2016).

7 Ismael Moreno, "The Increasing Presence and Threat of the Mining Industry in Central America," Promotio iustitiae, 118 (2015): 48-51.

8 Giorgio Truchi and Opera Mundi, "Crecimiento de la industria minera en Centroamérica produce mitos, paradojas y realidades trágicas," Movimiento Mesoamericana contra el modelo extractivo minero, September 9, 2014; available online at: http://movimientom4 .org/2014/og/crecimiento-de-la-industria-minera-en-centroamerica-produce-mitos -paradojas-y-realidades-tragicas/ (accessed June 21, 2016).

9 Ane Garay Zarraga, La minería transnacional en Centroamérica: Lógicas regionales e impactos fronterizos; El caso de la mina Cerro Blanco (Guatemala: Paz con Dignidad-omaL, 2014), 15-17.

10 See Alicia Bárcena, "Gobernanza de los recursos naturales en América Latina y el Caribe," in Seminario gobernanza de los recursos naturales en ALC (Santiago: Cepal, 2012), 32, http://www.cepal.org/sites/default/files/presentation/files/240424_presentaci onse_slides23abril-haconabi.pdf (accessed June 13, 2016). For an elaboration of the 
not necessarily mean that the governments have access to a fair and an appropriate share of the revenue from this sector. In order to attract the foreign investors - and especially mining companies-Latin American governments frequently ease the conditions for extractive activities, by loosening environmental regulations, relaxing the protection of human rights, and deregulating compensation measures with local communities who would be most disaffected by these industries. ${ }^{11}$

As a consequence of this current state of affairs, over the last few decades Latin American societies have witnessed an extraordinary expansion of environmental and territorial conflicts linked with mining activities. This is a direct consequence of intensified legal extraction by large companies, as well as illegal activities of other entities. According to the Observatorio de Conflictos Mineros de América Latina (ocmAL, Observatory of mining conflicts in Latin America), there are at least 210 mining conflicts in the region, thereby having a negative impact upon 315 local communities. The countries that have suffered most in this regard are Colombia, Chile, Brazil, and Mexico. ${ }^{12}$

In Colombia, for example, a steady increase in public protests against mining activities have occurred. According to the database on social conflict maintained by the Centro de Investigación y Educación Popular (CINEP, Center for research and popular education) — one of the region's most iconic Jesuit social centers ${ }^{13}$ - between 2010 and 2013, the protests and disturbances provoked by mining activities represented $7.61 \%$ of the total number of incidents

specific extraction industries of oil and natural gas, see Anthony Bebbington, "Extractive Industries, Socio-environmental Conflicts and Political Economic Transformations in Andean America," in Social Conflict, Economic Development and Extractive Industry: Evidence from South America, ed. Anthony Bebbington (London: Routledge, 2012), 3-26.

11 In December 2014, the Colombian Ministry of Environment enacted several norms to facilitate mining projects by reducing the requirement to obtain environmental license. Environmental lawyers and activists alike swiftly criticized such regulation denouncing such measures that would simplify the process for mining corporations, thereby might produce socio-environmental conflicts in the territories where such projects are planned. See Andrés Bermúdez, "Consulta exprés para las licencias," October 23, 2014, available online at: http://lasillavacia.com/historia/consulta-expres-para-las-licencias-48952 (accessed June 1, 2016).

12 Ocmal, "Mapa de conflictos mineros, proyectos y empresas mineras en América Latina," March 1, 2014, http://mapa.conflictosmineros.net/ocmal_db/ (accessed June 13, 2016).

13 One of CINEP's main missions is to develop means to promote a better understanding of the reality of the Colombian society. In order to promote such goal, this institution uses a comprehensive database collecting data since its foundation in 1972. The gathered information allows researchers to understand the historical trends and the current situation regarding social protest, collective actions for peace, human rights, and armed conflict. 
recorded for the country. In comparative perspective, that same category represented only $0.31 \%$ of occurrences in the period between 1979 and 2009. ${ }^{14}$ Moreover, this unrest is occurring throughout Colombia. Administratively, the nation is divided into thirty-two departments, and twenty-seven have witnessed public efforts related to mining activities. The groups that engage in these types of struggles tend to be peasant and ethnic communities-mostly rural, of Afro-descent or indigenous people - the miners and their unions, as well as environmental activists. Furthermore, the areas where mining tends to be carried out are frequently insufficient in terms of security and compliance with international standards of social and economic rights.

Consequently, the population of the mining provinces customarily live in a sort of paradox. As neighbors to mining activities that generate large revenue streams for companies and-theoretically - the local, regional, and national governments, they themselves have only precarious or limited access to social welfare. Overwhelmingly, they suffer from a lack of economic opportunities, from the direct negative externalities of mining, and from the complex situation of the absence of state institutions and social policies. ${ }^{15}$ In general terms, the Colombian state has not generated sufficient capacity in the mining regions to attend to social demands or to provide an answer to what have become embittered social and environmental conflicts. This lamentable situation, of course, is not exclusive to Colombian mining regions, and can be found in other Latin American countries, particularly Peru. ${ }^{16}$

The cumulative circumstances, outlined above, have generated unsustainable conditions that are the underpinnings of the current social and environmental situation, which can be illuminated from at least two perspectives. On the one hand, humanity as a whole faces the risk of reaching-and surpassing - a peak of extraction of raw materials during the twenty-first century. On the other hand, the increased intensity of the social and environmental conflicts caused by mining and other highly contaminant activities might indicate the source of new and uncertain forms of violence, and cycles of cruelty.

14 Mauricio Archila, Martha Cecilia García, Leonardo Parra, and Ana María Rodríguez, "Luchas sociales en Colombia, 2013," Anuari del conflicte social 2013 (2013): 553-611.

15 Guillermo Rudas and Jorge Enrique Espitia, "La paradoja de la minería y el desarrollo: Análisis departamental y municipal el caso de Colombia," in Minería en Colombia: Institucionalidad y territorio, paradoja y conflictos, ed. Luis Jorge Garay (Bogotá: Contraloría General de la República, 2013), 27-84.

16 Javier Arellano-Yanguas, "Mining and Conflict in Peru: Sowing the Minerals, Reaping a Hail of Stones," in Social Conflict, Economic Development and Extractive Industry: Evidence from South America, ed. Anthony Bebbington (London: Routledge, 2012), 89-111. 
As a result, the work being performed by Jesuit social centers, particularly in Latin America, must constantly confront the emergence of environmental and territorial conflicts that are inextricably linked with mining activities. Generally, an absolute commitment is acknowledged with the weakest actors of such conflicts, namely the rural communities, which encounter the enduring presence of mining companies. Nevertheless, the work of Jesuit social institutions is complicated, and furthermore many collaborators have faced precarious situations for the simple fact that being an environmental and land rights defender is highly dangerous. ${ }^{17}$ Yet threats against advocacy work on mining issues do not constitute a total impediment. This is the complex context in which Jesuit social centers pursue their work.

\section{Advocacy of the Jesuit Social Centers: An Integral Approach to a Complex Issue}

In order to provide support to local communities that are affected by mining - and this includes not only large-scale mining that is carried out by multinational or national companies but also illegal mining executed by medium-sized investors - several Jesuit social centers in Latin America, such as CINEP in Colombia, ERIC in Honduras, Cefasa in the Dominican Republic, ${ }^{18}$ and Fomento in Mexico, ${ }^{19}$ have developed human rights-based strategies for research, education, accompaniment, and advocacy.

\section{Research on Mining Impacts: Building Knowledge from below}

One of the major challenges of advocacy work on mining issues is the lack of reliable data and information, especially regarding the environmental impacts upon local communities that live in close proximity to areas of extraction. In many countries, the official data is not available for public use, and it

17 See Global Witness, How Many More? (London: Global Witness, 2015), available online at: https://www.globalwitness.org/en/campaigns/environmental-activists/how-many -more/ (accessed June 13, 2016). Global Witness identified Latin America as a region where it is especially dangerous to operate as an environmental activist and a land rights defender. In 2014, 116 environmental and land rights defenders were murdered, twenty-five of them were engaged in conflicts caused by mining of the extraction of natural resources from their territories. Specifically, Brazil, Guatemala, and Colombia are considered the most dangerous countries of the region for being an environmental defender.

18 Centro de Formación y Acción Social y Agraria (CEFASA), http://cefasa.com/ (accessed June 27, 2016).

19 Fomento Cultural y Educativo, http://www.fomento.org.mx/ (accessed June 27, 2016). 
consequently becomes a standing challenge to gain access to such information in the interest of advocacy.

It is also critical to develop strategies that foster a firm basis of knowledge within local communities from below. In other words, such a complex task emerges in developing participatory research strategies that might lead to the documentation of the impacts of mining activities on various dimensions of the day-to-day life. Accordingly, such information might begin to answer pressing questions regarding mining activities, such as: How is mining affecting the livelihoods of a specific rural community? Which mining-caused transformations of their territory affects basic economic activities, such as agriculture, fishing, or cattle-ranching? What impact does mining have on their culture and traditions? How has mining disenabled forms of political participation of local communities? What is the main impact on the environment and on the health conditions of local communities, among others? For many Jesuit social centers, this has materialized in the formulation and implementation of research projects that are oriented to solve such predicaments, using the research outcomes as a means to advocate in favor of disaffected communities. Researchers at Jesuit social centers identified one distinctive characteristic, having deployed research projects that genuinely solicited and fostered the participation of the people from the local communities. The result is a kind of community-based participatory research model, of which there are several examples of this mode of research and engagement throughout Latin America.

For instance, from 2012 to 2015, CINEP researchers in Colombia developed projects to investigate the local history and concurrently to provide records on the impacts of large-scale coal mines that are situated in the department of La Guajira, which is located in the Caribbean region of Colombia, with sizable local communities of both the wayúu indigenous community and an Afro-descendant population. This process of knowledge-building, on the part of researchers, subsequently engaged several key members of the local communities. With such specific research projects, the local history of rural communities of indigenous background and of Afro-descent, who were previously disaffected by large-scale mining, are being documented. The impacts upon culture, territory, and environment are presently available in scientific publications, and such information is suitable for advocacy work. ${ }^{20}$

20 Several of such consequences have been documented and analyzed. For instance, regarding the economy, one of the most significant ones is the reduction of land available for agriculture. In "El Hatillo" community, a peasant's village composed of 112 families, the area suitable for cropping was reduced from two hundred hectares to zero in less than 
This particular type of research project that Jesuit social centers, like CINEP, host has also fostered a dialogue between social sciences such as history, geography, law, and anthropology, with these sources of community-based knowledge. Several outputs validate this statement. For instance, the communities and the researchers of CINEP created elaborate maps that elucidate the territorial transformations rural communities experienced as a result of mining in the region. Additionally, all the relevant information is customarily presented to the communities as a pedagogical handbook that is didactically suitable for use within the community itself, so that the local history is effectively reconstructed and written in a book. ${ }^{21}$ As a result of this whole process, the capabilities of local community members are strengthened with support of evidence and facts that are directly related to the operations of large-scale mining.

A collaboration between Saint Louis University (SLU) — an American Jesuit university - and Equipo de Reflexión, Investigación, y Comunicación (ERIC, Reflection, research, and communication team), a Honduran social center of the Jesuits, is another relevant example of this research strategy that was conducted with the financial support of the Jesuit Conference of Canada and the United States. With respect to this research project, these two Jesuit institutions aim to "generate rigorous and reliable evidence on the social and environmental impact of mining and extractive activities to inform and support organizational, educational, and advocacy initiatives in Honduras, the U.s., and Canada."22 By virtue of pursuing this line of research, these institutions are mutually committed to a participatory study to assess the environmental impacts of the potential construction of large-scale mines in rural communities, particularly those located in Honduras's northern regions. During the fieldwork, a mixed group of researchers from ERIC and SLU's College for Public Health and Social Justice conducted 206 surveys in three target-areas with specific questions about basic needs, environmental health, and opinions about mining, and simultaneously collected water samples from 134 sources. Without question, this research and the subsequent policy papers will provide a significant precedent in terms of data access for rural communities that are involved in such struggles against the installation of large-scale mining endeavors in their territories.

fifteen years. See CINEP, Transformaciones territoriales en la comunidad de El Hatillo: Un recorrido por los impactos de la minería de carbón (CINEP: Bogotá, 2013).

21 Ibid.

22 Fernando Serrano, "Mining, Development and Justice in Honduras: A Community-based Initiative for Education and Advocacy," paper presented at the "Networking for Justice" seminar, Loyola, Spain, November 18, 2015. 


\section{Education and Accompaniment Strategies: Reaching Communities Disaffected by Mining}

For many communities affected by large-scale or illegal mining there are structural difficulties to gaining access to judicial mechanisms in order to demand fulfillment of their rights or even the reparation for the environmental, social, and cultural damage that may be caused by these kinds of mining activities. At least two reasons help explain such a situation: firstly, within these communities, there is a general lack of knowledge of the responsibilities of national institutions particularly with regard to the protection of the human rights of communities such as these; secondly, when the communities have access to that information, they do not have the means to perform a strategy-oriented approach to demanding protection or-more simply put-they do not have sufficient political power to deploy it.

At least, since the beginning of the 199os, several Jesuit social centers have developed education strategies with communities disaffected by mining, the main purpose of which is to build capacities amongst the leaders of each community in order to employ integral strategies to demand fulfillment of their human rights. ${ }^{23}$ Such educational programs are focused on specific areas, such as relevant legal frameworks, communication skills, negotiation techniques, and legal advocacy tools. In light of such experience, community leaders prospectively can improve their knowledge of how the national government should function; how they as local leaders can encourage the establishment of the most just scenario in order to negotiate with mining companies and with the national state; how they can adopt community-oriented strategies in order to make their situation and demands visible for a larger audience; and finally, how legal instruments that are available for their use can be accessed even without the requirement of an attorney. ${ }^{24}$ Nevertheless, the education strategies may be insufficient to transform the unequal scenario that is typically faced by those communities who are disaffected by mining activities. Consequently, it is necessary to develop and support advocacy strategies that might raise their collective profile and that, by catching the attention of key stakeholders, may make favorable choices in the interest of these grassroots communities.

23 Some of such projects have been analyzed and documented. See Nancy Arévalo, "Preguntas y desafíos: Apuestas para una formación con perspectiva de derechos humanos, económicos, sociales y culturales DHESC," Controversia 183 (2004): 103-25.

24 The documentation of this particular educational initiative with key leaders of communities affected by mining in currently being developed as an input for a certified course on Ignatian advocacy. It is supported by the social coordinator of the Latin American Conference. 


\section{Advocacy Strategies: An Attempt to Balance Power Asymmetries}

Through their fieldwork, Jesuit social centers developed an integral approach to complement the effectiveness of advocacy strategies that are basically oriented to influence key stakeholders and decision-makers in favor of the communities' demands. Such strategies may involve the following: interventions towards national or international judicial authorities, petitions to specific public institutions, especially those that control the activities of administrative authorities, such as the offices of the comptroller or the ombudsman.

An instance of such a Jesuit program is CINEP in Colombia, which has developed an advocacy strategy for influencing the judiciary proceedings of the Corte Constitucional de Colombia, the most important judicial authority in terms of human rights protection. In 2015, the court imparted to several state institutions orders to provide attention and solutions to the water crisis - and expressly the lack of recognition of water as a basic human right - which peasant communities of indigenous- and Afro-descent were suffering in the southern parts of the department of La Guajira, a region where large-scale coal mining was occurring for nearly thirty years. ${ }^{25}$ Those communities, having participated in research and education projects with CINEP, were supported in taking such legal action through the center, which reflects the Jesuit commitment to accompaniment. The case set a crucial precedent for their demands, and also an important precedent for similar communities in Colombia.

On the other hand, other social centers also facilitated the intervention of international judicial authorities, particularly those associated with the InterAmerican Commission of Human Rights (IACHR). ${ }^{26}$ During this commission's 2015 public hearings, ERIC—-the Honduran Jesuit social center-took part in several hearings on the subject of the precarious position of human rights defenders who are working in regions disaffected by mining activities. At that time, the ERIC representative highlighted the threats and risks that are constantly encountered by the human rights defenders who denounce the impact and human rights abuses caused by large-scale mining companies. With the power to dictate precautionary measures that would direct the states to prevent potentially irrevocable damage, the IACHR agreed with ERIC and the other petitioners declaring the inequity of such a situation on account of the

25 For further information on this specific topic, please consult the judgment's text: "Sentencia T-256/15," available at: http://www.corteconstitucional.gov.co/relatoria/2015/t-256-15 .htm (accessed June 13, 2016).

26 In Spanish, this commission is known as Comisión Interamericana de los Derechos Humanos (CIDH). 
disproportionate influence of mining companies upon state institutions and its officials, and even the mass media. ${ }^{27}$

Such endeavors and advocacy strategies that Latin American Jesuit social centers perform seem to be striving toward an integral approach that merges various activities such as community-based research, education, support, and strategic advocacy. These actions belong to an agenda whose broad and indirect purpose is the promotion of environmental justice. Jesuit reflections and especially the call from Pope Francis in his encyclical, Laudato si', provide illustrations of connecting the implications of an environmental issue like mining with a comprehensive strategy to care for the environment. ${ }^{28}$

\section{Environmental Justice}

The works and means of environmental activists vary widely, and so they cannot be considered as representatives of a univocal position on account of the variety of their proposals and the type of work that they pursue and-even more importantly - with whom they are working. The relevant question at this point of the article is which stream of environmentalism is the most proximate to the missions of the Jesuit social centers in Latin America. One particular author, Joan Martínez Alier, identifies at least three tendencies within the environmental movement: the environmentalism of the wilderness; the "gospel" of eco-efficiency; and the environmental justice movement, or the environmentalism of the poor. ${ }^{29}$

Environmentalism of the wilderness, the first tendency, characterizes the concern of its activists for the protection and preservation of vast, or key, areas of ecosystems that, in their perspective, should remain unperturbed by

27 According to Moreno, Honduras's mining companies continue to "develop propaganda campaigns aimed at discrediting the value of the struggles organized by communities against mining" (Moreno, "The Increasing Presence and Threat of the Mining Industry," http://www.southworld.net/central-america-the-increasing-presence-and-threat-of-the -mining-industry/ [accessed July 8, 2016]).

28 See Francis, Laudato si', especially n. 29, 51, and 146, available online at http://w2.vatican .va/content/francesco/en/encyclicals/documents/papa-francesco_20150524_enciclica -laudato-si.html (accessed June 13, 2016).

29 Joan Martínez Alier, The Environmentalism of the Poor: A Study of Ecological Conflicts and Valuation (Cheltenham: Edward Elgar, 2002). The explanation of each of these tendencies can be found in "Environmentalism of the Wilderness," 1-5; "The 'Gospel' of Ecoefficiency," $5^{-10}$, and "The Environmental Justice Movement or the Environmentalism of the Poor," 11-16. 
human activities. Such statement lacks a deep reflection on other urgent environmental issues. The second tendency, that is the so-called "gospel" of eco-efficiency, which emphasizes the sustainable use of natural resources in economic endeavors, while also arguing for the minimization of ecological externalities of industries, agriculture, cattle-ranching, and simply for the just compensation for environmental services. The third tendency, environmental justice, draws attention to the emergence of socio-environmental conflicts that are caused by economic growth and social inequality. This specific tendency highlights that both the urban and the rural poor, and other socially excluded communities, typically bear the burden of the ecological externalities and contamination. While clarifying in terms of motivation and ethical strategies, activists who are representative of these various tendencies, nevertheless, can eventually find ways and purposes to collaborate. For instance, rural communities disaffected by mining might be supported by activists from the "environmentalism of the wilderness," who besides helping such communities to recognize their territorial rights, can also promote the protection of strategic ecosystems that are threatened by mining expansion. ${ }^{30}$

Despite these diverse strategies Jesuit social centers in Latin America may deploy, and which are oriented to tackle the impacts of mining conflicts, their collective actions are more intimately linked with the approach of environmental justice than with the other modes of environmental activism. At least two reasons support such a claim. Firstly, as stated above, the researchers and collaborators of Jesuit social centers usually develop activities that are oriented to support poor rural communities who are disaffected by social, environmental, and economic impacts of mining activities. Thus, a clear intent to confront mining conflicts by working with the weakest is exhibited in such efforts. However, this does not necessarily suggest that a dialogue between relevant stakeholders is not also being concurrently promoted. In fact, Ignatian identity and the corporate membership of an institution, such as the Society of Jesus, might provide these social centers with the type of sensibility that facilitates their advocacy work as they interact with strong economic and political stakeholders. Secondly, through their advocacy work, the process of environmental degradation is frequently linked with the largest dimensions of political economy. In other words, environmental issues are fundamentally a major facet of a critique of the present political economy. As a result, environmental conflicts are presented and understood in these Jesuit circles as another manifestation of a wider mechanism of social exclusion that tends to victimize indigent communities. 


\section{Another Contribution: Francis's Call to Care for Our Common Home}

Moreover, the strategy of environmental justice parallels the types of theological approaches Jesuits tend to foster in addressing issues like mining conflicts. From such a theological standpoint, environmental degradation may be seen as an indicator of collective sin that is committed by humankind against the earth and its natural resources. Subsequently, the kind of social structure that sustains this collective sin might be confronted with a structure of grace that embodies a salutary power to repair the world. With respect to these ecological threats, local communities throughout Latin America, and Jesuit social centers as their partners, must address such circumstances in their concrete experience, for example, in their defense of territories while claiming reparations or in the wake of catastrophic occurrences..$^{31}$ Laudato si' vociferously affirms such an ethical position.

In this historic document, Pope Francis highlights the importance of the protection of "our common home" and how humankind should recognize its dependence on ecological equilibrium, which is severely altered by our constant intervention in the form of mining, forestry, oil extraction and agribusiness, for instance. At one point in the encyclical, Francis warns specifically of the deleterious effects that are caused by mining projects particularly regarding life, dignity, and livelihoods of local communities and the integrity of their territories-especially when such communities are under pressure to abandon their land in order to facilitate the installation of such extractive enterprises. ${ }^{32}$ Furthermore, many researchers and advocates, who are working in Jesuit social centers, are interpreting the pope's call for a dialogue on mining issues as an ethical mandate to accompany the urban and rural poor, and other socially excluded grassroots communities. Practically speaking, the cultivation

31 Frank Turner, S.J., "Natural and Mineral Resources: A Theological Reflection," Ecojesuit, February 28, 2015, http://www.ecojesuit.com/natural-and-mineral-resources-a-theologi cal-reflection/7674/ (accessed June 13, 2016).

32 See Francis, Laudato si', n. 146: "It is essential to show special care for indigenous communities and their cultural traditions. They are not merely one minority among others, but should be the principal dialogue partners, especially when large projects affecting their land are proposed. For them, land is not a commodity but rather a gift from God and from their ancestors who rest there, a sacred space with which they need to interact if they are to maintain their identity and values. When they remain on their land, they themselves care for it best. Nevertheless, in various parts of the world, pressure is being put on them to abandon their homelands to make room for agricultural or mining projects which are undertaken without regard for the degradation of nature and culture." 
of democratic dialogue about mining conflicts does not necessarily mean the assumption of impartiality on those moral issues. Instead, in the case of Latin American Jesuit social centers, it can be regarded as an intent to fortify the most vulnerable.

Whether mining activities will be reinforced and expanded in Latin American countries in the next several years — or even decades — remains uncertain. However, the work of environmental justice that is exemplified in the mission of Jesuit social centers may still be reinforced and extended to the multitudinous networks of the Society of Jesus. It is noteworthy that this work still remains the focus of the social apostolate of the Society of Jesus, but such reflection is not yet disseminated to its networks in other areas, particularly Jesuit educational institutions.

\section{Conclusion}

The apparent economic boom that revolves around the extraction of minerals and other raw materials in Latin American countries caused disproportionately negative consequences for local communities, which suffer at a personal, social, and an environmental level. Latin American Jesuit social centers, as a result, are engaged in advocacy and in forms of support to accompany local communities in the mining areas, creating relevant knowledge of a variety of socio-environmental issues. The emergent Latin American environmentalist model is one of environmental justice, which is grounded in the concrete experiences of these disaffected communities. 